\title{
PERBANDINGAN TEPUNG SORGUM DENGAN UMBI GANYONG DAN KONSENTRASI GLISEROL MONOSTEARATE (GMS) TERHADAP KARAKTERISTIK COOKIES TERFORTIFIKASI ZAT GIZI MIKRO
}

\author{
The Comparison of Sorghum with Canna Tuber Flour and Glycerol Monostearate \\ Concentration (GMS) Toward To The Characteristics of Micronutrient Fortified Cookies
}

\author{
Wisnu C. ${ }^{*}$, Yusep I. ${ }^{1}$, Surachman S. ${ }^{2}$, Farida N. ${ }^{3}$ \\ 1)JurusanTeknologi Pangan Fakultas Teknik, Universitas Pasundan, Bandung, Indonesia \\ 2)Politeknik Pembangunan Pertanian Bogor, Kementan RI \\ ${ }^{3)}$ Mahasiswa Magister Teknologi Pangan Pascasarjana, Universitas Pasundan, Bandung, Indonesia \\ *Korespondensi penulis, Email: wisnu.cahyadi@unpas.ac.id
}

Diterima: April 2019

Disetujui terbit: November 2019

\begin{abstract}
The benefits of this research was to obtain the right comparison of the sorghum flour substitution and canna tuber flour with GMS concentrationand toward to the characteristics of cookies. The purpose of the this research was to determine the effect of sorghum flour with canna tuber flour and the addition of GMS to obtain good characteristics of cookies that can be accepted by the community based on taste, color, and taste as well as fiber levels. So it can make people more interested in local food products with high nutritional value and increase the utilization of food sources in Indonesia. The experimental design used in this research was a factorial $3 \times 3$ pattern in a Randomized Block Design (RBD) with 3 replications to obtain 27 combinations of experiments. The treatment design consists of 2 factors, namely the ratio of sorghum flour and canna flour $(A)$ and GMS concentration $(B)$ in making cookies. The results of the preliminary study showed that the selected treatment to be used in the main research was treatment of $a_{2} b_{1}$, the product with formulation II with roasting time for 10 minutes. The main results showed that the first factor was the ratio of sorghum flour with canna tuber flour affecting the chemical response, namely water content and organoleptic response, namely the attributes of color, aroma, and texture but had no effect on flavor attributes. Then the second factor is the GMS concentration only affects the texture response, but does not affect other attributes, namely color, aroma and taste and chemical response, namely water content. The interaction between the two did not affect the chemical response and the observed organoleptic response. Based on the results of chemical analysis and organoleptic test, the selected treatment is a1b1 (ratio of sorghum flour with 70:30 canna flour and 0,5\% GMS concentration) which has a water content of $2.44 \%$, protein $6.125 \%$, fat $9.6013 \%$, starch $74,3571 \%$, the total number of microbes was $2.20 \times 102 \mathrm{cfu} / \mathrm{g}$, Fe $42.081 \mathrm{ppm}$ and iodine levels were $65.804 \%$ and the results of the analysis of hardness were $2792.15 \mathrm{gForce}$ and the ease of fracture was $19.00 \mathrm{~mm}$.
\end{abstract}

Keywords : cookies, sorghum flour, canna flour, Fe, iodine

\begin{abstract}
ABSTRAK
Manfaat dari penelitian ini adalah untuk mendapatkan perbandingan yang tepat dari substitusi tepung sorgum dan tepung umbi ganyong dengan konsentrasi GMS dan terhadap karakteristik cookies. Tujuan dari penelitian ini adalah untuk mengetahui pengaruh tepung sorgum dengan tepung umbi ganyong dan penambahan GMS untuk mendapatkan karakteristik cookies yang baik yang dapat diterima oleh masyarakat berdasarkan rasa, warna, dan rasa serta kadar serat. Sehingga bisa membuat orang lebih tertarik dengan
\end{abstract}


produk makanan lokal dengan nilai gizi tinggi dan meningkatkan pemanfaatan sumber makanan di Indonesia. Desain eksperimental yang digunakan dalam penelitian ini adalah pola faktorial 3x3 dalam Rancangan Acak Kelompok (RAK) dengan 3 ulangan untuk mendapatkan 27 kombinasi percobaan. Desain perlakuan terdiri dari 2 faktor, yaitu rasio tepung sorgum dan tepung ganyong (A) dan konsentrasi GMS (B) dalam membuat cookies. Hasil studi pendahuluan menunjukkan bahwa perlakuan yang dipilih untuk digunakan dalam penelitian utama adalah pengobatan a2b1, produk dengan formulasi II dengan waktu pemanggangan selama 10 menit. Hasil utama menunjukkan bahwa faktor pertama adalah rasio tepung sorgum dengan tepung umbi canna mempengaruhi respon kimia, yaitu kadar air dan respon organoleptik, yaitu atribut warna, aroma, dan tekstur tetapi tidak berpengaruh pada atribut rasa. Kemudian faktor kedua adalah konsentrasi GMS hanya mempengaruhi respon tekstur, tetapi tidak mempengaruhi atribut lainnya, yaitu warna, aroma dan rasa dan respon kimia, yaitu kadar air. Interaksi antara keduanya tidak mempengaruhi respon kimia dan respon organoleptik yang diamati. Berdasarkan hasil analisis kimia dan uji organoleptik, perlakuan yang dipilih adalah a1b1 (rasio tepung sorgum dengan 70:30 tepung ganyong dan konsentrasi 0,5\% GMS) yang memiliki kadar air 2,44\%, protein 6,125\%, lemak 9,6013\%, pati 74, 3571\%, jumlah total mikroba adalah 2,20x102 cfu / g, Fe 42,081 ppm dan kadar yodium 65,804\% dan hasil analisis kekerasan adalah 2792,15 gForce dan kemudahan patah tulang adalah $19,00 \mathrm{~mm}$.

Kata kunci: cookies, tepung sorgum, tepung ganyong, Fe, yodium

\section{PENDAHULUAN}

Lima masalah gizi di Indonesia yaitu kurang energi protein (KEP), obesitas, anemia, kurang vitamin $A$ (KVA) dan gangguan akibat kekurangan iodium (GAKI). Gangguan akibat kekurangan iodium (GAKI) merupakan salah satu masalah gizi utama disamping masalah gizi lainnya. Hubungan antara zat iodium dengan kualitas SDM telah banyak diungkapkan oleh para ahli. Namun demikian, kekurangan iodium akan menyebabkan pembengkakan kelenjar tiroid/gondok pada leher (goiter).

Salah satu cara untuk menangani permasalah di atas adalah dengan fortifikasi yodium pada pangan. Fortifikasi pangan dengan zat gizi mikro adalah salah satu strategi utama yang dapat digunakan untuk meningkatkan status mikronutrien pangan. Fortifikasi harus dipandang sebagai upaya untuk memperbaiki kualitas pangan selain dari perbaikan praktekpraktek pertanian yang baik (Good Agricultural Practices), perbaikan pengolahan dan penyimpangan pangan (Good Manufacturing Practices), dan memperbaiki pendidikan konsumen untuk mengadopsi praktek-praktek penyediaan pangan yang baik (Siagian, 2003).

Masalah kekurangan gizi yang selama ini terjadi pada masyarakat akan diatasi dengan adanya fortifikasi pada produk panganyang dibuat, yang juga disertai dengan penambahan zat besi. Karena menurut Raharjo (2004), zat besi dapat menginisiasi terjadinya peroksidasi lemak dan juga oksidasi protein. Logam $\mathrm{Fe}$ dapat menginduksi terjadinya peroksidasi lemak, terutama pada rantai asam lemak tidak jenuh ganda. Lemak mengalami oksidasi ini akan menjalani reaksi lanjutan secara berantai membentuk produk radikal bebas seperti radikal alkil, radikal alkoksil, radikal peroksil, dan hidroperoksida. Peningkatan jumlah radikal ini akan mengakibatkan terjadinya dekomposisi asam lemak tidak jenuh menjadi lipid peroksida yang sangat tidak stabil. Oksidasi protein adalah modifikasi kovalen dari protein yang diinduksi baik secara langsung oleh spesies oksigen reaktif atau tidak langsung melalui reaksi dengan produk sekunder dari stres oksidatif (Astuti, 2014).

Dibalik keragaman cara untuk meningkatkan nilai gizi suatu produk pangan yang salah satunya adalah dengan cara fortifikasi, di Indonesia sendiri produk olahan pangan akhir-akhir ini mengalami perkembangan yang sangat pesat. Hal ini disebabkan oleh perubahan gaya hidup masyarakat yang ingin serba cepat sehingga produksi makanan pun mencari produk yang siap saji namun dapat mencukupi kebutuhan gizi setiap hari. Produk olahan yang banyak 
digemari masyarakat di Indonesia antara lain roti, biskuit, mie, dan termasuk cookies.

Cookies adalah makanan kering yang dibuat dari adonan lunak yang mengandung bahan dasar terigu, pengembang, kadar lemak tinggi, renyah dan apabila dipatahkan penampang teksturnya kurang padat. Bahan pembuat cookies dibagi menjadi dua menurut fungsinya yaitu bahan pembentuk struktur dan bahan pendukung kerenyahan, bahan pembentuk struktur meliputi tepung, susu skim dan putih telur sedangkan bahan pendukung kerenyahan meliputi gula, shortening, bahan pengembang, dan kuning telur. Telur yang ditambahkan berperan menghasilkan produk yang lebih baik, dapat memperbaiki proses creaming pemberian flavor yang khas serta kenaikan nilai gizi (Ulya, 2013).

Tepung terigu merupakan produk olahan gandum yang termasuk komoditi impor yang konsumsinya selalu meningkat dari tahun ke tahun. Kenaikan impor gandum tersebut untuk konsumsi terigu atas makanan yang berbasis tepung terigu. Hal ini terjadi karena gandum merupakan tanaman yang hanya bisa tumbuh di daerah subtropis, sehingga tidak dapat dibudidayakan di Indonesia.

Impor gandum hampir setiap tahunnya mengalami peningkatan, disebabkan dengan tingginya permintaan gandum antara lain terus terdorong oleh besarnya kebutuhan industri makanan dan pakan ternak yang terus meningkat di dalam negeri.Asosiasi Produsen Tepung Terigu Indonesia (Aptindo) mengungkapkan impor gandum di dalam negeri hingga saat ini diakui masih cukup tinggi. United States Department of Agriculture (USDA) memperkirakan impor gandum Indonesiaakan terus meningkat. Konsumsi gandum terbesar masih akan terserap oleh industri tepung terigu nasional, sementara sisanya, sebagian terserap untuk memenuhi kebutuhan sektor pakan ternak.

Masalah impor gandum yang terus meningkat dan masyarakat yang tidak dapat mengkonsumsi gluten atau produk olahan tepung terigu dapat ditanggulangi secara mendasar dan berkesinambungan melalui pemanfaatan sumber pangan lokal. Komoditas tanaman pangan yang dapat tumbuh dengan baik pada iklim tropis dan menghasilkan tepung sebagai pengganti tepung terigu diantaranya adalah sorgum dan umbi ganyong. Kedua jenis tepung ini berasal dari varietas tanaman yang banyak terdapat di Indonesia, yang penggunaannya belum dapat dimanfaatkan secara maksimal.

Sorgum merupakan tanaman yang termasuk family Gramineae, seperti padi, jagung, gandum, dan tanaman lain seperti bambu dan tebu (Kusmiadi 2011). Budidaya sorgum sudah dilakukan di beberapa daerah di Indonesia, terutama di Jawa, Sulawesi Selatan, Sulawesi Tenggara, Nusa Tenggara Barat (NTB) dan Nusa Tenggara Timur (NTT). Salah satu sifat khas dari sorgum adalah toleran terhadap kekeringan dan genangan. Sorgum mempunyai potensi besar untuk dikembangkan di Indonesia karena mempunyai daerah adaptasi yang luas.

Potensi dan keunggulan yang dimiliki sorgum antara lain dapat ditanam pada lahan suboptimal (lahan kering, rawa, dan lahan masam) yang tersedia cukup luas di Indonesia. Dengan produktivitas yang cukup tinggi, dan kandungan protein lebih tinggi dari beras. Luas panen dan produksi sorgum di Indonesia dari tahun 2005-2011 menunjukkan peningkatan sebesar $6,5 \%$ dan 6,2\%. Data terakhir yang didapatkan dari Direktorat Budidaya Serealia, Ditjen Tanaman Pangan pada tahun 2012 menyatakan bahwa luas panen sorgum di Indonesia mencapai 3.607 ha dengan produksi sorgum mencapai 7.695 ton. Sorgum mempunyai karakteristik yang lebih dekat dengan gandum sehingga berpotensi menggantikan terigu dan dapat menghasilkan gula.

Menurut Suarni (2004), sorgum mempunyai kandungan pati sekitar $80,42 \%$, lemak $3,65 \%$, protein $10,11 \%$, abu $2,24 \%$, serat kasar 2,74\%. Sorgum merupakan bahan pangan alternatif yang menempati urutan kelima setelah beras, jagung, dan gandum bagi penduduk di Benua Asia dan Afrika, dan menempati urutan serealia kelima terpenting sebagai bahan pangan manusia yang 
dikonsumsi oleh lebih dari 500 juta orang di lebih dari 30 negara.

Bahan pangan lokal selain sorgum yang dapat dimanfaatkan sebagai bahan pengganti tepung terigu adalah umbi ganyong. Indonesia merupakan negara yang sangat kaya dengan keragaman plasma nutfah termasuk umbiumbian. Lebih dari 30 jenis umbi-umbian yang biasa ditanam dan dikonsumsi rakyat Indonesia diantaranya adalah umbi ganyong. Pengembangan tepung ganyong memiliki nilai strategis sebagai pangan alternatif dalam rangka diversifikasi pangan berbasis sumber daya lokal. Hal ini nantinya dapat memperkuat ketahanan pangan di Indonesia dan meningkatkan pertumbuhan ekonomi di Indonesia.

Tanaman ganyong dibudidayakan secara teratur di daerah Purwerejo, Klaten, D.I.Yogyakarta, dan Wonosobo (Jawa Tengah) dan Jawa Barat meliputi daerah Bandung, Garut, Karawang, Lebak, Subang, Ciamis, Cianjur, Majalengka, dan Sumedang (Rukmana, 2000).

Ganyong cukup berpotensi sebagai sumber hidrat arang. Menurut Wiharto, (2017) menyebutkan bahwa kandungan gizi ganyong tiap $100 \mathrm{~g}$ secara lengkap terdiri dari air 79,9 g; energi $77 \mathrm{kkal}$; protein 0,6 g; lemak 0,2 g; karbohidrat $18,4 \mathrm{~g}$; serat $0,8 \mathrm{~g}$; abu $0,9 \mathrm{~g}$; kalsium $15 \mathrm{mg}$; fosfor $67 \mathrm{mg}$; besi $1,0 \mathrm{mg}$; vitamin C $9 \mathrm{mg}$; dan tiamin 0,10. Tepung ganyong memiliki kelebihan dibandingkan tepung terigu, yaitu berserat tinggi dan tidak mengandung gluten. Masyarakat yang mengalami gangguan pencernaan atau sensitif terhadap protein (gluten), tetap dapat mengkonsumsinya. Ganyong merupakan tanaman yang berpotensi mengandung karbohidrat dalam bentuk gula kompleks seperti serat dan kemungkinan juga zat-zat metabolik sekunder yang diperlukan untuk kesehatan seperti alkaloid, flavonoid, steroid dan fenolik (Noriko dan Pambudi, 2014).

Tujuan penelitian adalah (1) untuk mengetahui pengaruh substitusi tepung sorgum dengan tepung umbi ganyong dan konsentrasi GMS terhadap karakteristik cookies terfortifikasi zat gizi mikro (besi dan iodium), dan (2) mendapatkan produk cookies terfortifikasi yang berkualitas dan dapat diterima oleh masyarakat sebagai produk pangan lokal.

\section{BAHAN DAN METODE PENELITIAN Bahan dan Alat Penelitian}

Bahan-bahan yang digunakan dalam pembuatan cookies ini adalah tepung sorgum, tepung umbi ganyong, kuning telur, margarine, baking powder, vanili, susu bubuk, gula halus, gliserol monostearat, $\mathrm{FeSO}_{4}$ dan $\mathrm{KIO}_{3}$.

Bahan-bahan yang digunakan untuk analisis kimia adalah kalium iodida, reagen Luff Schoorl, $\mathrm{Na}_{2} \mathrm{~S}_{2} \mathrm{O}_{3}$, pelarut heksan, $\mathrm{KMnO}_{4}, \mathrm{HCl}$ pekat, $\mathrm{H}_{2} \mathrm{SO}_{4}$, amilum, $\mathrm{H}_{2} \mathrm{SO}_{4}$ encer, $\mathrm{NaOH}$, dan aquadest.

Alat-alat yang digunakan dalam penelitian adalah oven, timbangan digital, mixer, sendok, loyang, cetakan semprit, spatula dan baskom.

Alat-alat yang digunakan untuk analisis kimia yaitu desikator, kaca arloji, oven, timbangan digital, penjepit, kuvet, corong pisah, gelas ukur, kolorimeter, spektrofotometer UVVis, tabung reaksi, rak tabung, penangas air, pipet tetes dan volumetri, beaker glass, kertas saring, labu ukur $100 \mathrm{~mL}$, erlenmeyer, gelas ukur, gelas kimia, pemanas, lumpang dan mortil.

\section{Metode Penelitian}

Penelitian yang dilakukan yaitu penentuan perbandingan antara tepung sorgum dan tepung ganyong. Rancangan perlakuan terdiri dari 2 faktor, yaitu perbandingan tepung sorgum dan tepung ganyong (A) dan konsentrasi GMS (B) pada pembuatan cookies.

Faktor pertama yaitu perbandingan tepung sorgum dan tepung ganyong $(A)$ yang terdiri dari 3 taraf, yaitu :

$\mathrm{a}_{1}=60: 40$

$\mathrm{a}_{2}=65: 35$

$\mathrm{a}_{3}=70: 30$

Faktor kedua yaitu konsentrasi GMS (B) terdiri dari 3 taraf, yaitu :

$\mathrm{b}_{1}=0,5 \%$

$b_{2}=1 \%$

$b_{3}=1,5 \%$ 
Rancangan percobaan yang digunakan dalam penelitian ini adalah pola factorial $3 \times 3$ dalam Rancangan Acak Kelompok (RAK) dengan 3 kali ulangan sehingga diperoleh sebanyak 27 kombinasi percobaan.

Rancangan respon dalam penelitian ini meliputi respon kimia yaitu analisis kadar air metode gravimetri (AOAC, 2005), respon organoleptik yaitu uji hedonik terhadap warna, aroma, rasa dan kerenyahan, serta respon terpilih yaitu kadar lodium (Spektrofotometri), kadar Fe (AAS), analisis kadar protein (metode Kjeldahl), kadar lemak (metode shoklet), kadar karbohidrat (metode Luff Schoorl) dan texture analyzer pada produk terpilih.

\section{Prosedur Penelitian}

\section{Deskripsi Penelitian}

1. Pencampuran bahan I

Pencampuran bahan I bertujuan untuk mencampurkan margarin, gula halus, dan kuning telur. Proses pencampuran bahan I berlangsung selama 10 menit dengan menggunakan mixer. Kecepatan putar mixer yang digunakan adalah 800 rpm. Bahan yang akan dicampurkan dimasukkan ke dalam baskom, kemudian aduk hingga rata menggunakan mixer sampai terbentuk krim.

\section{Proses Fortifikasi}

Pada Proses ini ditambahkan juga bahan fortifikan yaitu Fe 200 ppm dan iodium 300 ppm ke dalam adonan pada saat proses pencampuran I.

\section{Pencampuran bahan II}

Pencampuran bahan II bertujuan untuk mencampurkan bahan hasil pencampuran I dengan vanili, susu bubuk, baking powder, GMS serta tepung umbi ganyong dan tepung sorgum. Proses pencampuran bahan II dilakukan sampai adonan bercampur rata dengan menggunakan mixer. Kecepatan putar mixer yang digunakan adalah $600 \mathrm{rpm}$. Perbandingan antara tepung umbi ganyong dengan tepung sorgum yang ditambahkan yaitu 60:40, 65:35 dan 70:30. Kemudian konsentrasi GMS yang digunakan yaitu $0,5 \%$, $1 \%$ dan $1,5 \%$. Semua bahan dicampurkan terlebih dahulu di dalam wadah kosong, kemudian dicampurkan ke dalam baskom yang telah berisi bahan hasil pencampuran I, lalu diaduk menggunakan mixer. Bahan yang sudah tercampur akan membentuk adonan yang siap untuk dicetak.

\section{Pencetakan}

Pencetakan bertujuan untuk membentuk adonan cookies sesuai dengan keinginan. Alat yang digunakan pada proses pencetakan adalah cetakan semprit dan loyang. Adonan yang akan dicetak ditekan sehingga akan keluar adonan kue yang berbentuk seperti bunga diatas loyang yang telah diolesi oleh margarin.

\section{Pemanggangan}

Pemanggangan bertujuan untuk mengeringkan sekaligus mematangkan adonan. Proses pemanggangan berlangsung pada suhu $160^{\circ} \mathrm{C}$ dengan lama pemanggangan sesuai dengan waktu pemanggangan terpilih pada penelitian pendahuluan. Alat yang digunakan pada proses ini adalah oven. Adonan hasil pencetakan diletakan di atas loyang, kemudian dimasukkan ke dalam oven untuk dipanggang. Selama pemanggangan berlangsung terjadi perubahan, seperti perubahan warna menjadi kecokelatan dan pengurangan densitas produk cookies karena pengembangan tekstur berpori (perubahan tekstur). Cookies siap diamati.

6. Pengamatan

Pengamatan yang dilakukan adalah respon kimia meliputi kadar karbohidrat, kadar lemak, kadar protein, kadar zat besi dan kadar yodium, respon fisik yaitu pengukuran kekerasan dan kemudahpatahan menggunakan alattexture analyzer, respon mikrobiologi yaitu Total Plate Count dan E. Coli serta respon organoleptik terhadap atribut warna, aroma, tekstur dan rasa untuk mendapatkan produk terpilih dari seluruh perlakuan. 


\section{HASIL DAN PEMBAHASAN}

Perlakuan terpilih pada penelitian ini ditentukan dengan analisis statistik metode skoring. Berdasarkan data yang diperoleh dari hasil perhitungan metode skoring maka dapat diambil suatu kesimpulan untuk menentukan sampel terpilih pada penelitian ini. Hasil analisis statistik metode skoring penentuan perlakuan terpilihcookies dapat dilihat pada Tabel 1.

Tabel 1. Hasil Skoring Penentuan Perlakuan

\begin{tabular}{ccccccc} 
& \multicolumn{5}{c}{ Terpilih } \\
\cline { 2 - 6 } Perlaku & \multicolumn{5}{c}{ Organoleptik } & \multicolumn{3}{c}{ Kimi } \\
an & \multicolumn{5}{c}{ Tot } & \\
\cline { 2 - 6 } & Warn & Arom & Ras & Tekst & Air & al \\
& a & a & a & ur & & \\
\hline a1b1 & 4 & 4 & 1 & 4 & 2 & 15 \\
a1b2 & 3 & 4 & 2 & 3 & 1 & 13 \\
a1b3 & 2 & 2 & 2 & 2 & 1 & 9 \\
a2b1 & 3 & 2 & 4 & 2 & 2 & 13 \\
a2b2 & 3 & 3 & 3 & 2 & 2 & 13 \\
a2b3 & 2 & 3 & 1 & 1 & 2 & 9 \\
a3b1 & 2 & 1 & 2 & 2 & 4 & 11 \\
a3b2 & 2 & 2 & 4 & 1 & 4 & 13 \\
a3b3 & 1 & 1 & 3 & 1 & 4 & 10 \\
\hline
\end{tabular}

Keterangan : Perbandingan tepung sorgum : ganyong ( $\left.a_{1}=60: 40 ; a_{2}=65: 35 ; a_{3}=70: 30\right)$, Konsentrasi GMS ( $\left.b_{1}=0,5 \% ; b_{2}=1 \% ; b_{3}=1,5 \%\right)$

\section{Berdasarkan penentuan produk terpilih menggunakan metode skoring didapatkan hasil yaitu $a_{1} b_{1}$ dengan perbandingan tepung sorgum dan tepung umbi ganyong 70:30 serta konsentrasi GMS $0,5 \%$, dengan kadar air 2,92\%. Hasil perlakuan terpilih kemudian dilakukan analisis kimia yaitu kadar karbohidrat (pati), protein, lemak, yodium, Fe, daya serap air, texture analyzer, serta analisis TPC dan E.Coli.}

\section{Produk Tepilih}

Respon perlakuan terpilih seperti yang terlihat pada Tabel 1 dilakukan untuk mengetahui pengaruh perbandingan tepung tepung sorgum dengan ubi ganyong dan konsentrasi GMS terhadap respon kimia pada produk. Hasil analisis kimia perlakuan terpilih dapat dilihat pada Tabel 2.

Tabel 2. Hasil Analisis Kimia Perlakuan Terpilih

\begin{tabular}{|c|c|c|c|}
\hline \multirow{2}{*}{ No } & \multirow{2}{*}{ Pengujian } & \multicolumn{2}{|c|}{ Hasil } \\
\hline & & SNI & $a_{1} b_{1}$ \\
\hline 1 & Kadar Air & Maks. 5 & $2,92 \%$ \\
\hline 2 & Protein & Min. 5* & $6,125 \%$ \\
\hline 3 & Lemak & Min. 9,5 & $9,6013 \%$ \\
\hline 4 & Pati & Min. 70 & $74,3571 \%$ \\
\hline 5 & $\begin{array}{l}\text { TPC (Total } \\
\text { Plate Count) }\end{array}$ & - & $2,20 \times 10^{2} \mathrm{cfu} / \mathrm{g}$ \\
\hline 6 & E.Coli & - & 0,0 APM \\
\hline 7 & $\mathrm{Fe}$ & - & 42,041 ppm \\
\hline 8 & Yodium & $\begin{array}{l}\text { 30-80 } \\
\text { ppm }\end{array}$ & 65,804 ppm \\
\hline
\end{tabular}

\section{Analisis Kadar Protein Cookies}

Protein adalah suatu senyawa organik yangmempunyai berat molekul besar antara ribuan hingga jutaan satuan $(\mathrm{g} / \mathrm{mol})$. Protein merupakansumber asam amino yang mengandung unsurC, $\mathrm{H}, \mathrm{O}$ dan $\mathrm{N}$ yang tidak dimiliki oleh lemak dankarbohidrat (Winarno, 1997).

Hasil kadar protein pada sampel terpilih yang terkandung pada cookies yaitu 6,125\%. Hasil tersebut telah sesuai dengan SNI syarat mutu cookies yaitu $5 \%$. Kandungan protein yang tinggi cenderung akan menghasilkan cookies yang lebih keras serta tekstur dan permukaan yang lebih kasar.

Penambahan tepung sorgum, tepung umbi ganyong, telur serta susu yang juga mengandung protein dapat meningkatkan kadar protein yang ada pada produk cookies yang dihasilkan. Kadar protein tinggi akan meningkatkan daya serap air sehingga tekstur cookies yang dihasilkan akan kokoh. Tekstur suatu produk berkaitan dengan kadar air dan kadar protein di mana semakin tinggi kadar protein akan semakin menyerap air. Menurut Makmoer (2006), daya serap air tergantung dari mutu protein dan jumlah kandungan asam amino polar dalam protein tepung. 


\section{Analisis Kadar Lemak Cookies}

Lemak didalam makanan memegang peranan penting ialah lemak netral (glycerin).Lemak memiliki efek shortening pada makanan yang dipanggang seperti biskuit, kue kering dan roti sehingga menjadi lezat dan renyah. Lemak akan memecah struktur kemudian melapisi pati dan gluten, sehingga menghasilkan kue kering yang renyah (Haryanto, 2009).

Hasil kadar lemak pada sampel terpilih yang terkandung pada cookies yaitu $9,6013 \%$. Angka tersebut telah sesuai dengan SNI syarat mutu cookies tahun 1992 yaitu minimum 9,5\%. Hal ini disebabkan oleh adanya penambahan margarine yang mengandung kadar lemak yang tinggi. Menurut Hui (1996), margarine terdiri dari $80-81 \%$ total lemak.

Menurut Haryanto (2009), menyatakan bahwa lemak dapat memperbaiki struktur fisik seperti pengembangan, kelembutan, tekstur dan aroma. Tingginya kadar lemak disebabkan oleh bahan yang digunakan dalam pembuatan cookies yang cukup tinggi seperti margarin ataupun kuning telur.

Kemampuan (mutu) pengkriman lemak merupakan hal yang penting karena saat pengkriman, lemak akan memerangkap dan menahan sel-sel udara (Lopulalan, 2008). Waktu pencampuran yang berlebih akan merusak susunan yang terbentuk sehingga pengembangan cookies akan menurun. Derajat pengembangan berpengaruh terhadap tekstur produk. Produk yang lebih mengembang akan memiliki tekstur yang lebih renyah.

\section{Analisis Kadar Karbohidrat (Pati) Cookies} Karbohidrat (pati) adalah salah satu komponen penting dalam menentukan besarnya nilai daya serap air. Pati merupakan senyawa yang bersifat hidrofilik. Granula pati memiliki kemampuan menyerap air yang sangat besar karena jumlah gugus hidroksil pati yang sangat besar, oleh karena itu semakin tinggi pati maka kadar airnya semakin besar.

Karbohidrat berperan dalam menentukan karakteristik bahan makanan seperti warna, rasa, dan tekstur. Menurut Andarwulan, dkk
(2011), karbohidrat mengandung gula pereduksi yang berperan dalam reaksi pencoklatan non enzimatis (maillard) apabila bereaksi dengan senyawa yang memiliki gugus amino seperti protein.

Hasil kadar karbohidrat (pati) pada sampel terpilih yang terkandung pada cookies yaitu $74,3571 \%$. Hasil tersebut sudah memenuhi SNI syarat mutu cookies tahun 1992 yaitu minimum $70 \%$. Hal ini kemungkinan terjadi karena kadar karbohidrat yang dikandung dalam bahan baku tepung sorgum dan tepung umbi ganyong cukup tinggi, yaitu $66,9453 \%$ dan $71,1504 \%$.

\section{Analisis TPC dan E.Coli Cookies}

Aspek mikrobiologi mempunyai peranan penting dalam penilaian mutu produk pangan, karena beberapa jenis produk pangan cepat mengalami penurunan mutu akibat aktivitas mikroorganisme. Oleh karena itu, dilakukan pengujian jumlah mikroba total dalam produk cookies.

Data hasil jumlah mikroba dan E.Coli pada cookies dapat dilihat pada Tabel 2, dimana dari tabel tersebut menunjukkan bahwa jumlah mikroba pada cookies yaitu sebesar $2,20 \times 10^{2} \mathrm{cfu} / \mathrm{g}$. Faktor yang mempengaruhi pertumbuhan mikroba adalah penyediaan nutrient yang sesuai untuk kultivasi bakteri, faktor fisik dan juga faktor kimia. Meskipun medium yang digunakan beragam, namun mikroba mempunyai kebutuhan dasar yang sama yaitu meliputi air, karbon dan mineral.

Menurut Fardiaz (1992), semakin lama waktu penyimpanan, jumlah mikroorganisme semakin bertambah, hal ini juga terjadi pada suhu yang berbeda, karena suhu merupakan salah atu faktor yang mempengaruhi terhadap berkembangnya pertumbuhan mikroorganisme, karena setiap mikroorganisme memiliki suhu minimum, optimum dan maksimum.

Menurut Standar Nasional Indonesia (SNI 01-2973-1992) yaitu cemaran mikroorganisme pada cookies adalah maksimal $1 \times 10^{6} \mathrm{cfu} / \mathrm{g}$, maka berdasarkan hasil yang didapatkan dapat disimpulkan bahwa cookies yang dihasilkan masih aman untuk dikonsumsi karena masih memenuhi standar yang ditentukan. 
Pengujian E.Coli juga dilakukan terhadap cookies yang dihasilkan, dimana hasil yang didapatkan adalah 0,0 APM. Hal ini juga telah sesuai dengan Standar Nasional Indonesia (SNI 01-2973-1992) yang menyatakan bahwa standar E.Coli pada cookies adalah negative, sehingga produk cookies yang dihasilkan termasuk pangan yang bermutu, layak dikonsumsi, dan aman bagi kesehatan.

\section{Analisis kadar iodium Cookies}

Berdasarkan hasil pengujian kadar yodium didapat persentase penurunan dari jumlah yodium yang ditambahkan hingga kadar yodium yang ada pada produk cookies yang dihasilkan. Dimana kandungan yodium yang ditambahkan sebelum dilakukan pencampuran dan pemanggangan adalah sebanyak 296,729 ppm kemudian setelah proses pengolahan menjadi 47,767 ppm sehingga penurunan yang terjadi adalah sebesar $83,90 \%$.

Hasil di atas telah memenuhi standar SNI No. 01-3556 tahun 2000, yang menyatakan bahwa yodium yang ditambahkan dalam garam adalah sebanyak $30-80 \mathrm{mg} \mathrm{KIO} / \mathrm{kg}$ garam atau (30-80 ppm).

Berdasarkan data di atas menunjukkan kandungan akhir dan penurunan yodium pada cookies. Berkurangnya kadar yodium disebabkan adanya proses pemanasan saat pemanggangan. Proses pemanasan akan mengurangi kestabilan $\mathrm{KIO}_{3}$ dalam cookies. Seperti pada penelitian Nurani (2008), menyebutkan bahwa teknik pengolahan dengan pemberian garam di akhir memiliki $\mathrm{KIO}_{3}$ lebih banyak dibandingkan pemberian garam di awal pengolahan. Hal ini dapat dikarenakan pemberian garam diawal lebih banyak terjadi penguapan karena suhu panas pemasakan, sehingga lebih banyak yang menguap.

Menurut Yogaswara (2008) menyatakan bahwa kehilangan iodium disebabkan karena sifat iodium, yaitu mudah larut dalam air, mudah menguap serta mudah rusak bila terkena cahaya atau panas.

Penurunan ini diakibatkan ketika proses pelarutan $\mathrm{KIO}_{3}$ terdisosiasi menjadi ion $\mathrm{K}^{+}$dan $\mathrm{IO}_{3}{ }^{-}$(iodat). Akibat proses pemanasan, iodat berubah menjadi iodium. Iodium memiliki sifat yang mudah teroksidasi karena pengaruh pemanasan, sehingga kadar iodium dalam cookies ikut menurun. (Wihardika, 2015)

$\mathrm{KIO}_{3}$ dengan suhu tinggi akan terurai menjadi $\mathrm{I}_{2}$ kemudian $\mathrm{I}_{2}$ akan menguap selama proses penyimpanan dan pemasakan. Kinetika (perubahan) kemunduran mutu sangat penting baik dalam proses pengolahan maupun distribusi pangan. (Cahyadi, 2004)

\section{Analisis kadar Fe Cookies}

Berdasarkan hasil pengujian kadar $\mathrm{Fe}$ (zat besi) didapat persentase penurunan dari jumlah awal Fe yang ditambahkan hingga kadarFe yang ada pada produk cookies yang dihasilkan. Dimana kandungan $\mathrm{Fe}$ yang ditambahkan sebelum dilakukan pencampuran dan pemanggangan adalah sebanyak 92,105 ppm kemudian setelah proses pencampuran menjadi sebesar 51,53\%, setelah pemanggangan menjadi 42,041 ppm sehingga penurunan yang terjadi berturut-turut adalah sebesar $44,05 \%$ dan $54,35 \%$.

Hasil di atas menunjukkan bahwa terjadi penurunan dari jumlah $\mathrm{Fe}$ yang ditambahkan sampai dengan akhir proses pengolahan. Menurut Palupi (2010), sebenarnya secara umum mineral lebih tahan terhadap proses pengolahan dan selama penyimpanan dibandingkan vitamin.

Faktor lingkungan juga mempengaruhi kerusakan zat besi, diantaranya adalah panas, udara, cahaya dan kelembaban. Stabilitas zat besi tergantung dari beberapa faktor diantaranya adalah sifat alami bahan pembawa, ukuran partikel serta paparan terhadap panas, kelembaban dan udara. Maka dapat disimpulkan bahwa penurunan kadar Fe setelah proses pemanggangan terjadi karena adanya penggunaan suhu tinggi yaitu $160^{\circ} \mathrm{C}$.

Penurunan kadar $\mathrm{Fe}$ sebelum proses pemanggangan atau ketika masih dalam bentuk adonan dapat terjadi karena proses pencampuran yang kurang sempurna, atau hilang ketika proses pencampuran (mixing) menggunakan mixer karena salah satu sifat kimia dari zat besi adalah mudah bereaksi dengan oksigen. 


\section{Analisis Kekerasan dan Kemudahpatahan (Texture Analyzer)}

Hardness (Kekerasan) dan fracturability (kemudahan dipatahkan) dipandang sebagai dua indikator penting dalam menganalisis tekstur makanan terutama dalam produk-produk baked seperti roti dan biskuit (Pratama dkk., 2014). Kekerasan dapat diukur dengan cara merekam gaya maksimum yang dibutuhkan untuk menekan suatu bahan. Sedangkan kemudahan untuk dipatahkan diukur dengan mengkalkulasi gaya dan jarak yang dibutuhkan untuk menekan bahan sampai terjadinya crack (keretakan). Berdasarkan analisis yang telah dilakukan didapatkan hasil yang dapat dilihat pada Tabel 3.

Tabel 3. Hasil Pengujian Texture Analyzer Terhadap Cookies

\begin{tabular}{ccccc}
\hline No & $\begin{array}{c}\text { Parameter } \\
\text { Analisis }\end{array}$ & $\begin{array}{c}\text { Hasil } \\
\text { Analisis }\end{array}$ & $\begin{array}{c}\text { Satuan } \\
\text { Hasil }\end{array}$ & $\begin{array}{c}\text { Metode } \\
\text { Pengujia } \\
\mathrm{n}\end{array}$ \\
\hline 1 & $\begin{array}{c}\text { Kekerasan } \\
\text { Kemudah- } \\
\text { patahan }\end{array}$ & $\begin{array}{c}2792,15 \\
19,00\end{array}$ & $\begin{array}{c}\text { gForce } \\
\text { mm }\end{array}$ & Kompresi \\
\hline
\end{tabular}

Menurut Gaines et al (1992), kadar protein (gluten) dan kemampuan mengikat air berpengaruh pada kekerasan cookies. Makin tinggi kadar protein, makin tinggi kekerasan cookies. Menurut Belinda (2009), selama pemanggangan panas berpenetrasi dengan cepat pada bagian bawah dan atas cookies, menyebabkan hilangnya gas pengembang dan air pada bagian tersebut. Penetrasi panas ke bagian dalam cookies lebih lambat, memungkinkan terbentuknya lebih banyak rongga udara. Makin lambat air tertahan, memungkinkan makin banyak pati tergelatinisasi pada bagian tengah cookies. Jumlah rongga udara yang terbentuk dan gelatinisasi pati dipengaruhi oleh kecepatan perpindahan panas ke dalam cookies dan kecepatan hilangnya air. Makin banyak panas yang masuk, makin banyak rongga udara yang terbentuk dan lebih banyak pati yang tergelatinisasi. Hal ini akan mempengaruhi struktur remah pada cookies.

Menurut Winarno (1981), tekstur dapat dipengaruhi perbandingan amilosa dari tepung atau pati yang digunakan. Komposisi amilosa setiap pati berbeda-beda dan sangat menentukan sifat pengembanganya.Kandungan gula pada bahan juga sangat mempengaruhi tekstur produk cookies yang dihasilkan. Menurut Matz (1978), jumlah gula yang ditambahkan mempunyai pengaruh yang signifikan terhadap tekstur, penampakan produk, dan flavor. Sifat adonan dan respon adonan terhadap kondisi oven juga berkaitan dengan tipe dan jumlah gula yang ditambahkan.

Tekstur dari cookies juga dapat dipengaruhi oleh kadar air produk. Cookies memiliki kadar air 1- 5\% dan Aw yang rendah sehingga menurut Pratiwi (2008), kekerasan merupakan fungsi dari jumlah air yang terikat pada matriks karbohidrat. Kandungan air yang tinggi membuat cookies lebih keras dan sulit untuk dipatahkan sehingga menyebabkan tekstur kurang disukai. Semakin tinggi kadar air maka tekstur produk semakin tidak renyah begitu pula sebaliknya.

\section{SIMPULAN DAN SARAN}

Hasil penelitian pendahuluan menunjukkan produk cookies terpilih berdasarkan nilai rata-rata analisis statistik metode skoring terhadap respon kimia dan respon organoleptik adalah perlakuan $a_{2} b_{1}$ dimana formulasi yang terpilih ada formulasi II dengan lama pemanggangan selama 10 menit. Kadar air produk cookies yang dihasilkan yaitu sebesar $2,86 \%$.

Hasil penelitian utama produk cookies terpilih berdasarkan nilai rata-rata analisis statistik metode skoring terhadap respon kimia dan respon organoleptik adalah perlakuan $a_{1} b_{1}$ dengan perbandingan tepung sorgum dan tepung umbi ganyong sebanyak 70:30 dan konsentrasi GMS sebanyak 0,5\%. Perlakuan tersebut memiliki nilai kadar air sebesar 2,92\%, kadar protein 6,1255\%, kadar lemak 9,0613\%, kadar pati $74,3571 \%$ dan TPC sebanyak $2,20 \times 10^{2} \mathrm{cfu} / \mathrm{g}$ serta jumlah E.Coli yaitu 0,0 APM. 


\section{UCAPAN TERIMAKASIH}

Penulis mengucapkan terimakasih kepada Kementerian Ristek Dikti RI, Direktorat Jenderal Penguatan Riset dan Pengembangan, Direktorat Riset dan Pengabdian Masyarakat yang telah membiayai penelitian melalui skim Hibah Penelitian Strategi Nasional. dan Universitas Pasundan Bandung yang telah memfasilitasi penelitian ini.

\section{DAFTAR PUSTAKA}

Andarwulan., N, Kusnandar., F, Herawati. 2011. Analisis Pangan. Dian Rakyat, Jakarta.

Astuti, Rahayu., Aminah, Siti., dan Syamsianah, Agustin. 2014. Komposisi Zat Gizi Tempe Yang Difortifikasi Zat Besi dan Vitamin A Pada Tempe Mentah dan Matang. Universitas Muhammadiyah Semarang.

Badan Standardisasi Nasional. 2011. Biskuit. 2973 : 2011. Departemen Perindustrian, Jakarta.

Belinda. 2009. Evaluasi Mutu Cookies Campuran Tepung Kacang Hijau dan Beras Sebagai Pangan Tambahan Bagi Ibu Hamil. Skripsi: Institut Pertanian Bogor, Bogor.

Burt, D. J. dan Fearn, T. 1983. A Quantitative study of Biscuit Manufacture. Starch 35: 35 1-354.

Cahyadi, Wisnu. 2006. Analisa dan Aspek Kesehatan Bahan Tambahan Pangan. Jakarta: Penerbit Bumi Aksara.

Gaines, C. S., A. Kassuba, P. L. Finney dan J. R. Donelson. 1992. Instrumental Measurement of Cookie Hardness, Application to Product Quality Variables. Cereal Chemistry. 69:115-119.

Haryanto, B., Pangloli, P. 2009. Potensi dan Pemanfaatan Sagu. Kanisius. Yogyakarta.

Kusmiadi. 2011.2 Sorgum. http://riwankusmiadi.ubb.ac.id. Diakses: 15 April 2018.

Lopulalan, C. G. 2008. Kajian Formulasi dan Isotherm Sorpsi Air Biskuit Jagung.
Disertasi. Sekolah Pascasarjana Institut Pertanian Bogor : tidak diterbitkan.

Lufiria, Priskilla Yesi. 2012. Kadar Protein, Zat Besi, dan Mutu Organoleptik Kue Kering Berbahan Dasar Tepung Terigu dan Tepung Beras dengan Substitusi Tepung Sorgum (Sorghum bicolor L.Moench). Skripsi. Program Ilmu Gizi Universitas Diponegoro, Semarang.

Makmoer, H. 2006. Roti Manis\&Donat. Jakarta: PT.Gramedia Pustaka Utama.

Matoa. 2009. Ganyong: Alternatif Pangan Lokal dan Obat Tradisional. http://matoa.org/?p=230. Diakses: 02 Mei 2018.

Matz, S. A. 1972. Bakery Technology and Engineering, $2^{\text {nd }}$ Edition. The AVI Publishing Company Inc : Westport. Connecticut.

Matz, S. A. 1978. Cookies and Crackers Technology. The AVI Publishing Company Inc: Westport. Connecticut.

Matz, S. A. 1992. Bakery Technology and Engineering, $3^{\text {th }}$ Edition. Van Nostrand Reinhold. Texas.

Noriko, Nita., dan Pambudi, Arief. 2014. Diversifikasi Pangan Sumber Karbohidrat Canna edulis Ker (Ganyong). Fakultas Sains, Universitas Al-Azhar Indonesia.

Palupi, N. S. 2010. Fortifikasi zat besi. Food Review 5 (9): 49-52.

Raharjo, B. 2003. Faktor-Faktor yang Berhubungan dengan Anemia pada Pekerja Perempuan di Desa Jetis Kecamatan Sukoharjo Kabupaten Sukoharjo. Thesis Universitas Diponegoro.

Riskiani, Dani., Ishartani, Dwi., dan Rachawanti, Dian. 2013. Pemanfaatan Tepung Umbi Ganyong (Canna edulis Ker) Sebagai Pengganti Tepung Terigu Dalam Pembuatan Biskuit Tinggi Energi Protein Dengan Penambahan Tepung Kacang Merah (Phaseolus vulgaris L.). Universitas Sebelas Maret.

Rohajatien, U. 2010. Studi Tentang Pemrosesan Tepung Sorgum Terfosforilassi dan Aplikasinya pada 
Berbagai Adonan Pastri. Jurnal Teknologi dan Kejuruan, Vol.33, No.1.

Rukmana, R. 2000. Ganyong Budidaya dan Pasca Panen. Yogyakarta: Kanisius.

Sari, I. D. 2009. Nutrisi pada Pasien Autis. Cermin Dunia Kedokteran, 89 - 93.

Siagian A. 2003. Pendekatan Fortifikasi Pangan untuk Mengatasi Masalah Kekurangan Zat Gizi Mikro. USU digital library: Sumatra Utara.

Sindhuja A, Sudha ML, Rahim M. 2005. Effect of incorporation of amaranth flour on the quality of cookies. Eur Food Res Technol 221: 597-601.

Sirappa, M.P. 2003. Prospek Pengembangan Sorgum di Indonesia Sebagai Komoditas Alternatif untuk Pangan, Pakan, dan Industri. Balai Pengkajian Teknologi Pertanian Sulawesi Selatan, Makasar.

Slamet, Agus. 2010. Pengaruh Perlakuan Pendahuluan pada Pembuatan Tepung Ganyong (Canna edulis) Terhadap Sifat Fisik dan Amilografi Tepung yang Dihasilkan. Agrointek Vol 4, No. 2 : 100103.

Suarni, dan R. Patong. 2002. Tepung Sorgum Sebagai Bahan Substitusi Terigu. Jurnal Penelitian Pertanian 21(1):43-47.

Suarni. 2004. Pemanfaatan Tepung Sorgum Untuk Produk Olahan. Jurnal Penelitian dan Pengembangan Pertanian 23 (4):145-151.

Suarni. 2012. Potensi Sorgum sebagai Bahan Pangan Fungsional. Iptek Tanaman Pangan Vol.7 No.1.

Suarni. 2016. Peranan Sifat Fisikokimia Sorgum dalam Diversifikasi Pangan dan Industri serta Prospek Pengembangannya. Jurnal Penelitian dan Pengembangan Pertanian, Vol 35 No.3.

Sultan, W. J. 1983. Modern Pastry Chef Vol.1. The AVI Publishing Company Inc : Westport, Connecticut.

Sultan, W. J. 1969. Practical Baking. The AVI Publishing Company Inc : Westport, Connecticut.

Sutrisno, D. dan E.Djuwendah. 2016. Prospek Agribisnis Ganyong Sebagai Bahan
Pangan Alternatif. Fakultas Pertanian, Universitas Padjajaran.

Wihardika, L. 2015. Pengaruh Lama Pendidihan Terhadap Kadar $\mathrm{KIO}_{3}$ Pada Garam Dapur Beryodium Merk "X". Jurnal Wiyata, Vol. 2 No.2.

Wiharto, Indriastuti., Kurniawati, Linda., dan Karyantina, Merkuria. 2016. Karakteristik Cookies Dengan Substitusi Tepung Ganyong (Canna edulis Ker) Dengan Berbagai Perlakuan Pendahuluan. Universitas Slamet Riyadi.

Winarno, F. G. 1997. Kimia Pangan dan Gizi. Jakarta: Gramedia Utama.

Winarti, S. 2010. Makanan fungsional. Yogyakarta.

Winarti, S., dkk. 2017. Karakteristik Mi Kering dengan Substitusi Tepung Gembili dan Penambahan Gliserol Monostearat. UPN, Surabaya.

Yogaswara, G. 2008. Mikroenkapsulasi Minyak Ikan dari Hasil Samping Industri Penepungan Ikan Lemuru dengan Metode Pengeringan Beku. Skripsi: Program Studi Teknologi Hasil Perikanan. Fakultas Perikanan dan IImu Kelautan . Institut Pertanian Bogor, Bogor. 